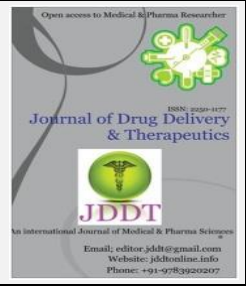

Open $\odot$ Access

Review Article

\title{
Silybum marianum (Milk Thistle): Review on Its chemistry, morphology, ethno medical uses, phytochemistry and pharmacological activities
}

\author{
Omji Porwal ${ }^{1}$, Muath Sheet Mohammed Ameen ${ }^{2}$, Esra T Anwer ${ }^{3}$, Subasini Uthirapathy ${ }^{4}$, Javed Ahamad ${ }^{4}$, \\ Amani Tahsin ${ }^{4}$ \\ ${ }^{* 1}$ Head of Department of Pharmacognosy, Tishk International University, Pharmacy Faculty, 100 Meter Street and Mosul Road, Erbil, KRG, \\ IRAQ \\ 2 Dean of Department of Pharmaceutics, Tishk International University , Pharmacy Faculty, 100 Meter Street and Mosul Road, Erbil, KRG, \\ IRAQ \\ ${ }^{3}$ Head of Department of Pharmaceutics, Tishk International University , Pharmacy Faculty, 100 Meter Street and Mosul Road, Erbil, KRG, \\ IRAQ
}

${ }^{4}$ Department of Pharmacy, Tishk International University, 100 Meter Street and Mosul Road, Erbil, KRG, IRAQ

\begin{abstract}
The oldest remedies identified to mankind are herbal medicines. India is recognized worldwide for its Ayurvedic treatment. India has rich history of using many plants for medicinal purposes. Remedial plants are cooperating extremely dynamic position in customary drugs for the action of a variety of illness. However a key obstacle, which has hindered the promotion in use of alternative medicines in the developed countries, is no evidence of documentation and absence of stringent quality control measures. There is a demand for the evidence of every investigate effort execute on conventional remedies in the appear ance of certification. The purpose of current review is to make accessible up-to-date information on, botany, morphology, ecological biodiversity, therapeutic uses, phytochemistry and pharmacological activities on diverse parts of Silybum marianum (L.) Gaertn (S. marianum). This review was assembled using technical literature from electronic search engine such as Springer link, Bio Med Central, Pub Med, Scopus, Science Direct, Scielo, Medline and Science domain. Supplementary texts were obtained from books, book chapters, dissertations, websites and other scientific publications. S. marianum a member of the Asteraceae family, is a tall herb with large prickly white veined green leaves and a reddish-purple flower that ends in sharp spines. It is native of the Mediterranean region and which has also spread in East Asia, Europe, Australia and America. It is grown as a commercial crop in several countries, including Iran and Pakistan. Confident chemical constituents were exposed cognate as silybin A, silybin B, isosilybin A, isosilybin B, silychristin, silydianin, apigenin 7-0- $\beta$ - $(2$ "0- $\alpha$-rhamnosyl)galacturonide, kaempferol 3-0- $\alpha$-rhamnoside-7-0- $\beta$-galacturonide, apigenin 7-0- $\beta$-glucuronide, apigenin 7-0- $\beta$ glucoside, apigenin 7-0- $\beta$-galactoside, kaempferol-3-0- $\alpha$-rhamnoside, kaempferol, taxifolin and quercetin. The plant is exclusively used as anti-diabetic, hepatoprotective, hypocholesterolaemic, anti-hypertensive, anti-inflammatory, anti-cancer, and as an antioxidant. Seeds of the plant are also used as an anti-spasmodic, neuroprotective, anti-viral, immunomodulant, cardioprotective, demulcent and anti-haemorrhagic. The plant is also serves as a galactagogue, agent that induces milk secretion and used in the treatment of uterine disorders. The plant is employed in dissimilar conventional schemes of remedy in the cure of different illness. The present paper enumerates the Pharmacognostic, morphological and ethnobotanical, pharmacological importance of the S. marianum, which may help the researchers to set their minds for approaching the utility, efficacy and potency of the plant.
\end{abstract}

Keywords: Medicinal plants, Silybum marianum, Asteraceae, Phytochemistry, Pharmacological

Article Info: Received 12 June 2019; Review Completed 01 August 2019; Accepted 19 August 2019; Available online 15 Sep 2019

\section{Cite this article as:}

Porwal O, Mohammed Ameen MS, Anwer ET, Uthirapathy S, Ahamad J, Tahsin A, Silybum marianum (Milk Thistle): Review on Its chemistry, morphology, ethno medical uses, phytochemistry and pharmacological activities, Journal of Drug Delivery and Therapeutics. 2019; 9(5):199-206 http://dx.doi.org/10.22270/jddt.v9i5.3666

\section{*Address for Correspondence:}

Prof. Dr. Omji Porwal Head of Department of Pharmacognosy, Tishk International University, Pharmacy Faculty, 100 Meter Street and Mosul Road, Erbil, KRG, IRAQ

\section{Introduction}

Plants are used for a variety of purposes. The history of natural products is relatively old and dates back to the time when the early man became conscious of his environment. Cultured and civilized man is said to have been on earth for some two or three million years and he has struggled for his life during the greater portion of the era. Thousands of years' effort by examination much has thought him to distinguishes between useful and harmful plants. Since then herbs have been used in all cultures as an important source of medicine ${ }^{1}$. The history of human culture and civilization of Egypt, 
Assyrian, China, and Indies valley, knows that the elders and wise man of those times used medicinal plants to treat many diseases. In sequence regarding these remedial plants is there in the previous text, mythological stories, folklore, medicinal treaties, epic poems and thousand years' old manuscripts, copper plates and palm leaves and other information on these cultures which are preserved even today. The unearth of Shanidar cave in Iraq in 1963 opened the grave of a Neanderthal man buried sixty thousand years ago along with so many flowers of his time. The plants there in the severe were afterward recognized to have numerous remedial assets ${ }^{2}$. Medicinal plants are the only inexpensive and reachable source of primary health care for them, particularly in the lack of access to contemporary medical facilities. Studies divulge that there are more conventional medicine providers than allopathic providers, particularly in rural areas ${ }^{3}$. Plant-resulting materials have recently befallen a huge consideration due to their adaptable appliances. Remedial plants are the wealthiest bio reserve of drugs of conformist structures of medication, food supplements, folk medicines, contemporary medicines, pharmaceutical intermediates and chemical entities for synthetic drugs ${ }^{4}$.

Medicinal plants form a huge group of inexpensively significant plants that provide the essential raw materials for indigenous pharmaceuticals ${ }^{5}$. Plant products still remain the most important source of pharmaceutical agents used in conventional medicine 6 . According to the WHO the primary step for recognition and purification of herbal drugs is the pharmacognostic (macroscopic and microscopic) studies that are necessary for any phytopharmaceutical products used for standard formulation ${ }^{7}$. Preliminary phytochemical studies are obliging in finding out chemical constituents in the plant material that may fine lead to their quantitative estimation ${ }^{8,9}$. Lately much concentration has directed towards extracts and biologically active compounds isolated from accepted plant species. In the present age of drug development and discovery of newer drug molecules, a lot of plant products are assessed on the basis of their conventional uses. The healing properties of medicinal plants are mostly due to the occurrence of various multifaceted chemical substances of dissimilar compositions which happen as secondary metabolites ${ }^{10}$. The most significant of these bioactive constituents of plants are steroids, tannins, alkaloids, flavonoids and phenolic compounds. Therefore, it is enviable to know the phytochemical composition of the plant material before testing its effectiveness for medicinal purpose. Plants are also main natural sources of medicinal compounds in present pharmacopoeias ${ }^{11}$. Indian Materia Medica comprises about 2000 drugs of natural origin and most of them are resulting from different conventional system and myths practices ${ }^{12}$. However, there are large numbers of plants, which have not been mentioned in these reports, in malice of their usage in the conventional and folk medicinal systems. S. marianum common name is milk thistle; it is an edible plant belongs to the Asteraceae family. It is an annual or biennial native to the Mediterranean regions of Europe, North Africa and the Middle East and in some parts of USA ${ }^{13}$. In India, it is commonly found in Jammu and Kashmir ${ }^{14}$. It grows to a height of three to ten feet with an erect stem that bears large, alternating, pricklyedged leaves.
The common name, milk thistle, is derived from the milky white veins on the leaves which, when broken open, yield a milky sap. Each stem bears single, large, purple flower ending in sharp spines. The fruit portion of the plant is glossy brown or drab with spots.

The plant grows at altitude of $1800-2400 \mathrm{~m}$ in rocky or sandy soil. The plant cherish with flowers in monsoon season from June to August 15 . Four different isomers were isolated from its secondary compound silymarin (silidianin isosilibinin, silibinin and silichristin) 16. S. marianum is hepatoprotectants for cancer Patients. Toleration of cancer therapy may progress from using this herb; reason is that it is blood and liver toxin clearing agents ${ }^{17}$. It has strong anticancer effects against breast, tumors, ectocervical and prostate ${ }^{18}$. Against the ovarian cancer, it enhanced the effectiveness of doxorubicin and cisplatin in vitro experiment ${ }^{19}$. S. marianum has been used safely for children ${ }^{20}$, older ${ }^{21}$ and pregnant women 22 . It is used in cholestatic, etiologies, viral, alcoholic and toxic effect removing medicines $^{23}$. The taxonomical classification of $\mathrm{S}$. marianum consists of Domain: Eukaryota, Kingdom: Plantae, Subkingdom: Viridaeplantae, Phylum: Tracheophyta, Subphylum: Euphyllophytina, Infraphylum: Radiatopses, Class: Magnoliopsida, Subclass: Asteridae, Superorder: Asteranae, Order: Asterales, Family: Asteraceae, Genus: Sylibum, Species: Marianum, Botanical name: Silybum marianum, Synonyms: Carduus marianus L. ${ }^{24}$ The common names of The common names of plant include blessed milk thistle, milk thistle, cardus marianus, marian thistle, variegated thistle,Saint Mary's thistle, Mary thistle, mediterranean milk thistle, wild artichoke,wild artichoke, christ's crown, our lady's thistle, holy thistle, venus thistle, heal thistle, wand of god's grace, marian thistle and scotch thistle (though not to be confused with Onopordum acanthium) 25. The vernacular names of the plant are English: Blessed milk thistle; thistle; Blessed milkthistle; Holy thistle; Lady's thistle; St. Mary's thistle, Dutch: Mariendistel, Vrouwendistel, Germany: Gemeine Mariendistel; Mariendistel, Spanish: Cardo asnal; Cardo blanco; Cardo lechero; Cardo mariano; Cardo santo; Poma, French: Chardon argente; Chardon marie; Chardon Notre Dame, Artichautsauvage, Portuguese: cardo-leiteiro, Italy: Cardo di Maria; Cardo mariano, Sweden: mariatistel, Netherlands: Mariadistel, Greek: Silybon, Malta: Blessed thistle, Romanian: Armurariu, Russian: Ostropestro, Swedish: Sempertin ${ }^{26}$. Therefore, in this study, the ethnopharmacological review of S. marianum was carried out aimed at providing a detailed précis of the botany, ethnomedicinal uses, pharmacological activities and chemical composition of the species.

\section{Research methodology}

To recognize pertinent information on the phytochemistry, botany, medicinal uses and biological activities of S. marianum, a review was amassed based on scientific literature from a variety of sources including Google Scholar, Science Direct, Pub Med, Scielo, Springer link, Google Patents, Web of Science, Sci Finder, Scopus, Espacenet, Bio Med Central (BMC) and Medline. The keywords employed for identification of pertinent information integrated different technical name and synonyms, ordinary english names and the stipulations: ethnobotany, medicinal uses, biological activities, ethnopharmacology, pharmacology, medicinal, Phytochemistry and therapeutic value, S. marianum, 
milk thistle Carduus marianus L, ect. Further literatures were finding from books, book chapters, theses, websites and conferencs.

\section{History}

The medical use of milk thistle has an extensive history. Theophrastus (c.371-287 BC), a Greek philosopher and successor to Aristotle, referred to milk thistle under the name of Pternix ${ }^{27}$. Pliny the Elder (23-79 C.E.) and Dioscorides (40-90 C.E.) both described this plant and its uses ${ }^{28}$. By the 16th century, milk thistle had become a favored medicine for hepatobiliary diseases ${ }^{29}$.In 1652 , Nicholas Culpeper, a preeminent English herbalist, wrote The English Physitian, in which he noted milk thistle to be an excellent remedy for obstructions of the liver and the spleen ${ }^{30}$.Milk thistle came to the Americas with the early European colonists. At the turn of the last century, the Eclectics, a group of herbalists, were using milk thistle extracts to treat liver, spleen, kidney and menstrual disorders ${ }^{31}$.Medical interest in this substance waned until the 1960s, when research studies primarily in Germany, re-focused attention on milk thistle and its constituents in the treatment of acute and chronic liver disease, and as a hepatoprotective agent to prevent toxic injury to the liver ${ }^{28}$.

\section{Occurrence and distribution}

Milk thistle is indigenous to the Mediterranean region and is widespread in Central Europe, Central, and Western Asia, North Africa, North and South America and Southern Australia 32, 33. It also grows in India, China, Africa and Australia. The plant was carried to North America by European colonists during the 19th century and is now naturalized in the United States and South America, Australia, China, and Central Europe 34 The plant was carried to North America by European colonists during the 19th century and is now naturalized in the United States and South America. Formerly cultivated in gardens, it is found in abandoned fields, old pastures and by the roadsides and, in some parts, is considered a problematic invasive weed and a target of classic biological control efforts ${ }^{35}$. It is commonly found in the provinces of Mazandaran, Gilan, West and East Azarbaijan, Kermanshah, Khuzestan, Fars and Bushehr ${ }^{36}$.

\section{Ecology}

Milk thistle adapts with different conditions climates. It can be cultivated in northern climates such as Canada as well as in southern and arid conditions ${ }^{37}$, because it is hardy and adaptable ${ }^{38}$. Morazzoni and Bombardelli (1995) asserted that the uppermost substance of silybin, the chief constituent of silymarin, is establish in sows from subtropical climates and not from moderate ones, because higher temperatures seem to enhance the accumulation of that compound. Milk thistle grows well and has a good yield on different soil types 39-41. Milk thistle is normally considered to be a weed that grows along roadsides and on wastelands 42 and reported as being a noxious weed in several countries because it competes with crops both for water and for nutrients 43 . Milk thistle proliferates best in nitrogen-rich media such as dairy yards, chicken coop waste, garbage dumps and abandoned agricultural fields ${ }^{40}$. The silymarin content in fruits depends on the milk thistle variety and geographic and climatic conditions in which they grow. However, the highest content of silybinin as the main component of silymarin is found in subtropical climates rather than from temperate climates ${ }^{36,40}$. Milk thistle is a nitrate accumulator and can be lethal when livestock ingests the plant, particularly in the early wilting stage ${ }^{44}$.

\section{Growing period}

Milk thistle grows as a winter annual or biennial herb, depending on climate. Germination occurs in autumn and spring 34 . Studies have shown that milk thistle seed germination is affected by light and temperature conditions ${ }^{42}$. Fresh milk thistle seeds seem to need an after-ripening period and germinate better at low temperatures compared to high temperatures. The seeds remain viable for 9 years or more. Young (1978) expressed that the incubated seeds in higher temperatures need for the longer after ripening period 45 . Melnikova (1983) reported that the minimum and maximum constant germination temperatures for $\mathrm{S}$. marianum are 10 and $35^{\circ} \mathrm{C}$ and optimum germination occurs at $20-25^{\circ} \mathrm{C} 45$. Ghavami and Ramin (2007) reported that the percentage of germination at $15^{\circ} \mathrm{C}$ was higher than in 25 and $35^{\circ} \mathrm{C}^{46}$. After the seedling establishment, milk thistle overwinters as a rosette and in the meanwhile basal leaf number were increasing. In late winter and early spring, milk thistle enters into the flowering stage when it receives a stimulus from low temperatures. Flowers a thesis occurs from April-May. The achenes (fruits) are ripe in July. The whole growth period of milk thistle was 125-140 day, which could be divided into the seedling stage (15-20 day), vegetative stage including two stages: rosette stage and stem elongation (45 - 60 day), flowering stage, fruit-bearing stages, and withering stages ${ }^{34}$. Within a capitulum, anthesis usually lasted five days. Ripe fruits were released about 17 days later. Individual plants had the potential to produce an average of 55 capitulum 47 . A single seed head can produce around 100-190 seeds. Flavonolignan accumulation in seeds depends on the stage of flower development and is maximum at the late flowering time ${ }^{41}$.

\section{Morphology}

S. marianum is an annual or biennial tubby, a rigid herb that is also wide and jagged. Unwieldy badge basal leaves produce up in its primary period, which reclines shut to the ground. It rises to a height of 2.5 meters and a width of 0.9 meters. Each plant produces up to four stems which are hollow, spherical and be full of milky white sap. It has big leaves that are wide and glossy green. They are distinct with white vein like marking, having spiny boundaries.

The grown-up leaves have deeper lobes with a wavier margin, while the young leaves are shallowly lobed with spin. The flowers of S. marianum are blue or white in color, thistle like and single. They have many tubular florets that are about $6 \mathrm{~cm}$ in diameter and are bordered by rigid bracts that end in sharp spines. After flowering, white, thick feathery thistledown develops and spreads the seeds. Seeds are obliquely obovoid and are 6-7 millimeters long and 3 millimeters wide. The color of the seeds is brown and has a yellowish extrapolative enlarged ring at its tip and a canaliculated hilum at other end 2 . In general, two types of $S$. marianum occur in some areas of Asia including purple flowers and white flowers. Single capitalism can produce up to 200 florets with color ranging from magenta to purple. In slash from corner to corner, the fruit demonstrates a thin, chocolate external region and 2 big, opaque, white oily cotyledons. Too the fruits are an 
elaiosome, plump arrangement on fruit that is wealthy in lipid and is gorgeous to ants and thus aids seeds dispersion. A significant dependence between the shapeliness of the fruits and the mass of 1000 fruits was indicated that biggest fruits had the highest mass and best vigor. Seeds in the secondary flower heads had a conspicuously lower weight, when compared to the primary ones. The plant size at the first bloom was reduced by postponing the sowing period from October to February. The same decreasing trend was observed in the number of flower heads and in the number of days required for the first bloom 48 .

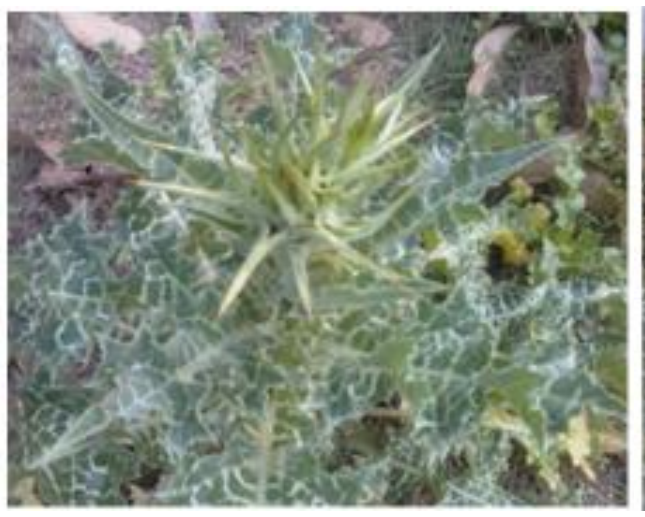

(A)

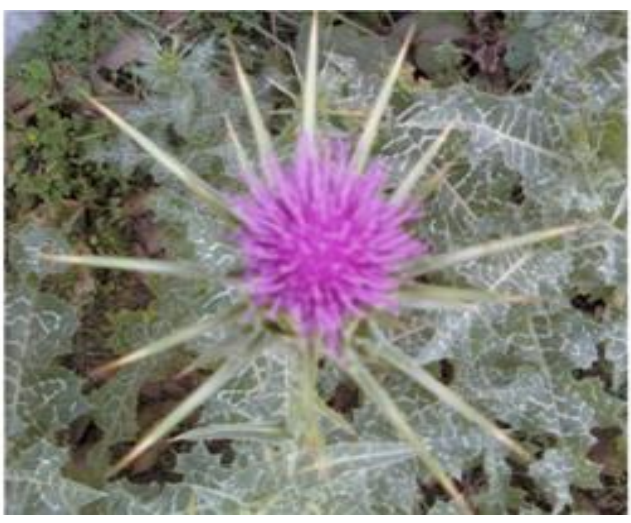

(B)

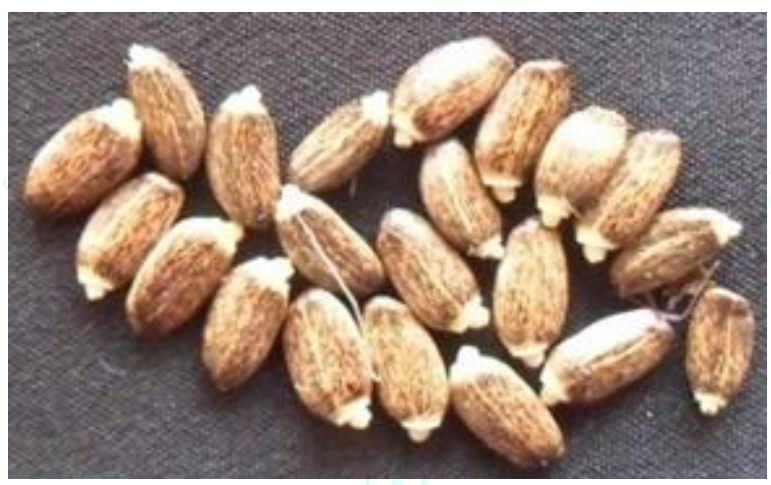

(C)

Figure 1 Silybum marianum (A) Plant (B) Flower (C) Seeds

\section{Microscopy}

Pericarp epidermis a colourless palisade layer of cells (about $75 \mathrm{~mm}$ long and $8 \mathrm{~mm}$ wide) with a strongly thickened outside wall, which reduces the lumen in that part of the cell to a slit; sub-epidermal layer composed of colourless, thinwalled, parenchyma cells or groups of parenchyma cells alternating with a variable number of pigmented cells; innermost layer mostly collapsed and containing cigarshaped or monoclinic prismatic crystals of calcium oxalate. Testa epidermis consists of large, lemon-yellow, palisadelike, elongated cells (about $150 \mathrm{~mm}$ long) with striated walls and narrow lumen widening slightly at the ends; sub-epidermal layers have lignified and pitted cells 49,50 .

\section{Phytochemical constituents}

The first indentified component of the flavonolignan complex of milk thistle, silybin (synonyms: silybinin, silibinin) including silybin A and silybin B was isolated and established by Pelter51,52; Silydianin (synonym: silidianin); Silychristin (synonym: silicristin and later renamed as silychristin A; Isosilybin A and Isosilybin B; Isosilychristin; 3-deoxyflavonolignans, silandrin and silymonin; Silyhermin, neosilyhermine $\mathrm{A}$ and neosilyhermine B; 2,3-dehydrosilybin; 2,3-cis-silybin A, 2,3-cis-silybin $B$ and neusilychristin; Isosilandrin A and isosilandrin B53 (Samu et al., 2004); Silychristin B, a diastereomer of silychristin A; Silyamadin; Isosilybin C and Isosilybin D. Mariamides A and B, 4-hydroxy-Nbenzamide, 4-hydroxy-N--benzamide, N,N-1,4butanediylbis (4-hydroxy-benzamide), 4,4'diphenylmethanebis (methyl) carbamates, taxifolin, dihydrokaempferol, dihydroquercetin-4'-methylether, naringenin, naringenin 7-0- $\beta$-D-glucopyranosid, kaempferol, coniferin, 3 -methylcarboxymethyl-indole$1-N-\beta$-D-glucopyranoside, and dehydrodiconiferyl alcohol-4- $\beta$-D-glucoside; donepezil, rutin, quercetin and morin; Taxifolin; (1R, 7R, 10R, 11R)-12-hydroxyl anhuienosol; 2-hydroxymethyl-5-(2-hydroxypropan-2yl)phenol; 2-(hydroxymethyl)-5-(2-hydroxypropan-2yl)phenyl $\beta$-D-glucopyranoside, (R)-2-(3-hydroxyl-4methylphenyl) propan-1-ol; Chlorogenic acid and caffeic acid54.

\section{Traditional uses}

In Europe, milk thistle is used in jaundice and other biliary affections. As a diet or in infusion it is said to be a reliable galactagogue. Silymarin is frequently used as helpful treatment in foodstuff toxic owing to fungus. Root: Root is eaten boiled as a potherb. Herb: Herb is used for intermittent fevers, dropsy \& uterine troubles. A decoction of it is said to be beneficial as an external application in cancer. Leaves: Leaves are sudorific and 
aperient. Juvenile leaves dish up as salad and blossoming skulls are inspired by diabetics. Seeds: Seeds are pungent, demulcent and antispasmodic. They are used for the treatment of jaundice and calculi of liver and gallbladder and are useful in controlling hemorrhages.

Alcoholic extracts of the seed and to a lesser extent of the plant together, increase the peristalsis of the small intestine and galenical preparations, both of the seed and oil are mild purgative. Seeds are used as a substitute for coffee ${ }^{55}$. Its flowers, leaves, and roots have been used as European diets as a vegetable, and its achene is used as a coffee. It considered a spinach substitute. The flower head is used for medicine. It is used as a remedy for Amanita mushroom toxins ${ }^{56}$.

\section{Mechanisms of action}

Silymarin's hepatoprotective effects are accomplished via several mechanisms including antioxidation, inhibition of lipid peroxidation and enhanced liver detoxification via inhibition of Phase I detoxification and enhanced glucuronidation and protection of glutathione depletion.

Reading have also revealed silymarin displays numerous anti-inflammatory property, including inhibition of leukotriene and prostaglandin synthesis, Kupffer cell inhibition, mast cell stabilization, and inhibition of neutrophil migration. In addition, silymarin has been shown to increase hepatocyte protein synthesis, thereby promoting hepatic tissue regeneration. Animal studies have also demonstrated silybin reduces the conversion of hepatic stellate cells into myofibroblasts, slowing or even reversing fibrosis. Clinical studies conducted in Hungary also demonstrated silymarin to have immunomodulatory effects on the diseased liver ${ }^{57}$.

\section{Pharmacokinetic}

Not solubility in water of Silymarin, making tea preparations ineffective; therefore it is usually administered orally in encapsulated form. Since incorporation of silymarin from the GIT is only temperate $(23-47 \%)$, it is best administered as a standardized extract of 70-80 percent silymarin. In animals and humans, peak plasma levels are reached in four to six hours after an oral dose. Silymarin is excreted primarily via the bile but some clearance is also achieved via the kidneys. The clearance half-life of silymarin is six to eight hours 58,59 .

\section{Dosage/toxicity}

S. marianum is typically given as a homogeneous extract (70$80 \%$ silymarin) in encapsulated form, $100-300 \mathrm{mg} 3$ times every day being the characteristic adult dose. Both animal and human studies have shown silymarin to be nontoxic. At high doses ( $>1500 \mathrm{mg}$ per day) a laxative effect is possible due to increased bile secretion and flow. Mild allergic reactions have also been noted but were not serious.

Reported pharmacological activities of $S$. marianum

\begin{tabular}{|c|c|}
\hline Activity & References \\
\hline Antioxidant activity & Admah et al 201360, Lucini et al 201661, Qin et al 2017a62, Nazir et al 201863, \\
\hline Inflammatory effects & Qin et al 2017b 64 \\
\hline Antiviral activities & Das et al 200865 , Cardile et al 201766 \\
\hline Antidiabetic activities & $\begin{array}{l}\text { Maghrani et al 200467, Qin et al } 2017 c^{68} \text {, Derosa et al } 2016^{69} \text {, Ebrahimpour- } \\
\text { Koujan et al 201570, Ebrahimpour-Koujan et al } 2018^{71}\end{array}$ \\
\hline Anti-amnesia effects & Nazir et al 201863, \\
\hline Cardio-protection & Vilahur et al $2018^{72}$, Ulas et al $2013^{73}$, Erel $2004^{74}, 2005^{75}$ \\
\hline Hepatic protection & $\begin{array}{l}\text { Shaker et al 201076, Aghazadeh et al 201177, Zhu et al 201878, Albassam } \\
2017^{79} \text {, Doehmer } 2011^{80}\end{array}$ \\
\hline Wilson's disease & Jedlinszki et al $2016^{81}$ \\
\hline Obsessive-Compulsive Disorder & Sayyah et al $2010^{82}$ \\
\hline Sepsis and Burn prevents & Toklu et al $200783,2008^{84}$ \\
\hline Application on veterinary & Cullere et al 201685, Kosina et al 201786 \\
\hline Hypocholesterolaemic Activity & Skottova and Krecman $1998^{87}$ \\
\hline Anti-hypertensive Activity & Jadhav et al 201188 \\
\hline Neuroprotective Activity & Kittur et al $2002^{89}$ \\
\hline Anti-cancer Activity & Bhatia et al 199990 \\
\hline Anti-aflatoxin activities & Alhidary et al 201791 \\
\hline Antidote activity & Fanoudi et al $2018^{92}$ \\
\hline
\end{tabular}

\section{Conclusion}

S. marianum is one of the most important medicinal plants grown in the world. This article reviews the phytochemistry, pharmacological, therapeutic applications and traditional knowledge of the plant $S$. marianum. The plant had been extensively used as a medicinal and legendary plant for a long period of time. S. marianum has attracted substantial attention due to its outstanding benefits. Pharmacological investigation on flavonolignans have been carry out in vitro and also urbanized in vivo in animal models and human experiments. Though several pharmacological mechanisms related to biological activity have already been explained, the comprehensive pharmacological mechanisms of the S. marianum need to be elucidated. Based on phytochemical and pharmacological research, the silymarins responsible for the good anti-diabetic, antiamnesia, hepatic-protective activities were selected as chemical markers to evaluate the quality of the $S$. marianum and its products.

Though, pharmacokinetics investigations on the chief constituents, particularly the bioactive constituents are silent mainly absent, so unyielding confirmation for more scientific claim is essential in regulate to review the therapeutic 
potential of the S. marianum and its pharmaceutical commodities such as cardio-protection activity.

\section{Acknowledgement}

Authors indebted acknowledge the facilities provided by Faculty of Pharmacy, Tishk International University, Erbil, Kurdistan Region, Iraq.

\section{Conflict of Interest: No conflict.}

\section{References}

1. Baquar SR. The Role of Traditional Medicine in Rural Environment, In: Traditional Medicine in Africa, Issaq, S. (Editor), East Africa Educational Publishers Ltd., Nairobi 1995, pp. 141-142.

2. Khan FA, Zahoor M, Ullah N, Khan S, Khurram M, Khan S, Ali J. A general introduction to medicinal plants and silybum marianum. Life Science Journal 2014; 11(9s): 471-481.

3. World Health Organization. Containing Antimicrobial Resistance: Review of the Literature and Report of a WHO Workshop on the Development of a Global Strategy for the Containment of Antimicrobial Resistance. WHO/ CDS/CSR/DRS/99.2; 1999.

4. Ncube NS, Afolayan AJ, Okoh AI, Assessment techniques of antimicrobial properties of natural compounds of plant origin: current methods and future trends, African Journal of Biotechnology 2008; 7: 1797-1806.

5. Aiyelaagbe 0 , Antibacterial activity of Jatropa multifida roots. Fitoterapia 2001; 72: 544-546.

6. Prince L, Prabakaran P. Antifungal activity of medicinal plants against plant pathogenic fungus Colletotrichum falcatum. Asian Journal of Plant Science Research 2011; 1: 84-87.

7. WHO, Quality control methods for herbal materials, Updated edition of Quality control methods for medicinal plant materials, 1998.

8. Rai VM, Pai VR, Kedilaya PH, Hegde S. Preliminary phytochemical screening of members of Lamiaceae family: Leucas linifolia, Coleus aromaticus and Pogestemon patchouli. International Journal of Pharmaceutical Science Review and Research 2013; 21(1): 131-137.

9. Lamaeswari G, Ananti T. Preliminary phytochemical screening and physicochemical characterization of Canna indica L.International Journal of Pharmaceutical Science Review and Research 2012; 14: 76-79.

10. Karthikeyan A, Shanthi V, Nagasathaya A, Preliminary phytochemical and antibacterial screening of crude extract of the leaf of Adhatoda vasica L. International Journal of Green Pharmaceae 2009; 3: 78-80.

11. Kingston DG. Modern natural products drug discovery and its relevance to biodiversity conservation. J Nat Prod 2011; 74:496-511.

12. Narayana DBA, Katayar CK, Brindavanam NB. Original system: search, research or research. IDMA Bull 1998; 29:413-6.

13. Hogan F, Krishnegowda N, Mikhailova M, Kahlenberg M. Flavonoid, silibinin inhibits proliferation and promotes cellcycle arrest of human colon cancer. J Surg Res2007; 143:5865.

14. Schuppan D, Jia J, Brinkhaus B, Hahn EG. Herbal products for liver diseases: A therapeutic challenge for the new millennium. Hepatology 1999; 30:1099-1104.

15. Bisset N. Herbal Drugs and Pharmaceuticals. CRC Press Boca Ratan, London, 1994, 121-123.

16. Lee DY, Liu Y.Molecular structure and stereochemistry of silybin A, silybin B, isosilybin A and isosilybin B, isolated from Silybum marianum (milk thistle). J Nat Prod 2003; 66: 11711174.

17. Ladas EJ, Cheng B, Hughes D. Milk thistle (Silybum marianum) is associated with reductions in liver function tests (LFTs) in children undergoing therapy for acute lymphoblastic leukemia (ALL). Society of Integrative Oncology, Boston, Mass 2006.

18. Bhatia N, Zhao J, Wolf DM. Inhibition of human carcinoma cell growth and DNA synthesis by silibinin, an active constituent of milk thistle: comparison with silymarin. Cancer Lett 1999; 147: 77-84.

19. Duthie SJ, Johnson W, Dobson VL. The effect of dietary flavonoids on DNA damage (strand breaks and oxidised pyrimdines) and growth in human cells. Mutat Res 1997; 390: 141-151.

20. Allain H, Schück S, Lebreton S. Aminotransferase levels and silymarin in de novo tacrine-treated patients with Alzheimer's disease. Dementia Geriatr Cogn Disord 1999; 10: 181-185.

21. Hernandez R, Nazar E. Effect of silymarin in intrahepatic cholestasis of pregnancy. Ethiopia 1982; 47: 22-29.

22. Greenlee H, Abascal K, Yarnell E, Ladas E. Clinical applications of Silybum marianum in oncology. Integr Cancer Ther 2007; 6: 158-165.

23. Eliss RH, Covell S, Roberts EH, Sumerfield RG. The influence of temperature on seed germination rate in grain legumes. II. Interspecific variation in chickpea (Cicer arietinum L.) at temperature. J Exp Bot 1986;37: 1503-1515.

24. http://www.zipcodezoo.com/Plants/S/Sylibum_marianum.

25. Patel CJ, Tyagi S, Kumar U, Patel S, Patel Ph, Bharat C. Clinical benefits of milk thistle (silybum marianum): a recent review. Journal of Drug Discovery and Therapeutics 2013; 1 (1): 08-11

26. Kirtikar KR, Basu BD. Indian Medicinal Plants, Vol. 2, International Book Distributors, Dehradun, 2006, 1417-1418.

27. Morazzoni P, Bombardelli E. Silybum marianum (Carduus marianus). Fitoterapia. 1995; LXVI: 3-42.

28. Luper S. A review of plants used in the treatment of liver disease: part 1. Altern Med Rev 1998; 3:410-421.

29. Schuppan D, Jia JD, Brinkhaus B, et al. Herbal products for liver diseases: a therapeutic challenge for the new millennium. Hepatology 1999; 30: 1099-1104.

30. Culpeper N. The English Physitian: Or an Astrologo-Physical Discourse of the Vulgar Herbs of This Nation. London: Peter Cole, 1652.

31. Giese LA. Complementary healthcare practices. Gastroenterol Nurs 2001; 24:38-40.

32. Libster M. Delmar's integrative herb guide for nurses. Thamson Learning. 2002, pp: 669 -77.

33. British Pharmacopoeia. Herbal Drugs and Herbal Drug Preparations Milk-thistle Fruit. 2009, Volume III. pp: 7173.

34. Das SK, Mukherjee S and Vasudevan DM. Medicinal properties of milk thistle with special reference to silymarin an overview. Natural Product Radiance 2008; 7 (2): 182- 92.

35. Groves RH, Kaye PE Aust J Bot 1989; 37:351

36. Ghahreman A. Flora of IRAN. Research Institute of Forests Rangelands, Iran, 1999; pp: 587.

37. Wallace S, Vaughn K, Stewart BW, Viswanathan T, Clausen E, Nagarajan S, Carrier DJ. Milk Thistle Extracts Inhibit the Oxidation of Low-Density Lipoprotein (LDL) and Subsequent Scavenger Receptor- Dependent Monocyte Adhesion. J Agric Food Chem 2008; 56: 3966-72.

38. Cwalina-Ambroziak B, Wierzbowska J, Damszel $M$ and eresa Bowszys T. The effect of mineral fertilization on achenes yield and fungal communities isolated from the stems of milk thistle Silybum marianum (L.) Gaertner. Acta Sci Pol Hortorum Cultus 2012; 11 (4): 157- 68.

39. Andrzejewska J, Sadowska K, Mielcarek S. Effect of sowing date and rate on the yield and flavonolignan content of the fruits of milk thistle (Silybum marianum L. Gaertn.) grown on light soil in a moderate climate. Industrial Crops and Products 2011; 33 (2): 462-8.

40. Morazzoni P, Bombardelli E. Silybum marianum (Carduus marianus). Fitoterapia 1995; 66: 3- 42.

41. Carrier DJ, Crowe T, Sokhansanj S, Wahab J and Barl B. Milk thistle, Silybum marianum L. Gaertn., flower head development and associated marker compound profile. J Herbs Spices Med Plants 2002; 10: 65-74.

42. Montemurro P, Fracchiolla M and Lonigro A. Effects of Some Environmental Factors on Seed Germination and Spreading Potentials of Silybum marianum Gaertn. Ital J Agron. / Riv Agron 2007; 3: 315-20.

43. Abenavoli L, Spagnuolo R, Luppino I, Luzza F. Recent progress in medicinal plants. Spllc Press. 2010, pp: 387-409.

44. Azim Khan M, Blackshaw RE, Marwat KB. Biology of milk thistle (Silybum marianum) and the management options for growers in North-Western Pakistan. Weed Biology and Management 2009; 9: 99-105.

45. Mel'nktov T M. Morphological-biological characteristics of Silybum marianum seeds as sowing material. Khimiko Farmatsevticheskii Zhurnal 1983; 17 (8): 958 - 63. 
46. Ghavami N, Ramin AA. Salinity and temperature effects on seed germination of milk thistle. Commun Soil Sci Plant Anal 2007; 38: 2681-91.

47. Dodd J. Phenology and seed production of variegated thistle, Silybum marianum (L.) Gaertn., in Australia in relation to mechanical and biological control. Weed Res 1989; 29 (4): 255- 63.

48. Qavami N, Naghdi Badi H, Labbafi MR, Mehrafarin A .A Review on Pharmacological, Cultivation and Biotechnology Aspects of Milk Thistle (Silybum marianum (L.) Gaertn.) Journal of Medicinal Plants 2013; 12 (47): 19-37

49. Anonymous. Fructus Silybi Mariae. In: WHO monographs on selected medicinal plants, Vol 2. World Health Organization, Geneva, 2002;300-301.

50. Dwivedi S, Khatri P, Rajwar S, Dwivedi A. Pharmacognostic and pharmacological aspects of potent herbal hepatoprotective drugs-A review. International Journal of Research in Pharmaceutical and Biomedical Sciences 2011; 2(2):492-499.

51. Pelter A, Hänsel R. The structure of silybin (silybum substance E6), the first flavonolignan. Tetrahedron letters. 1968; 9(25):2911-2916.

52. Pelter A, Hänsel R. Struktur Des Silybins: I. Abbauversuche. Chemische Berichte. 1975; 108(3):790-802.

53. Samu Z, Nyiredy S, Baitz-Gács E, Varga Z, Kurtán T, Dinya Z et al. Structure Elucidation and Antioxidant Activity of (-)-Isosilandrin Isolated from Silybum marianum L. Chemistry and biodiversity. 2004; 1(11):1668-1677.

54. Le QU, Lay HL, Wu MC, Joshi RK. Phytoconstituents and pharmacological activities of Silybum marianum (Milk Thistle): A critical review. American Journal of Essential Oils and Natural Products 2018; 6(4): 41-47.

55. Anonymous. The Wealth of India, A dictionary of Indian raw materials \& industrial products: Raw materials. Vol. IX: Rh-So, National Institute of Science Communication and Information Resources, New Delhi, 2005, 359-360.

56. Robbers JE, Tyler VE. Tyler's Herbs of choice: the therapeutic use of phytomedicinals. New York: Haworth Herbal Press 1999; p: 287.

57. Monograph, Silybum marianum (Milk Thistle). Alternative Medicine Review 1999; 4 (4): 272-274.

58. Schandalik R, Gatti G, Perucca E, et al. Pharmacokinetics of silybin in bile following administration of silipide and silymarin in cholecystectomy patients. Arzneimittelforschung 1992; 42:964-968.

59. Tyler V. Herbalgram 1994; 30:24-30.

60. Ahmad N, Abbasi BH, Fazal H. Evaluation of antioxidant activity and its association with plant development in Silybum marianum L. Industrial Crops and Products. 2013a; 49:164168.

61. Lucini L, Kane D, Pellizzoni M, Ferrari A, Trevisi E, Ruzickova G et al. Phenolic profile and in vitro antioxidant power of different milk thistle [Silybum marianum (L.) Gaertn.] Cultivars. Industrial Crops and Products. 2016; 83:11-16.

62. Qin NB, Jia CC, Xu J, Li DH, Xu FX, Bai J et al. New amides from seeds of Silybum marianum with potential antioxidant and antidiabetic activities. Fitoterapia. 2017a; 119:83-89.

63. Nazir N, Karim N, Abdel-Halim H, Khan I, Wadood SF, Nisar M. Phytochemical analysis, molecular docking and antiamnesic effects of methanolic extract of Silybum marianum (L.) Gaertn seeds in scopolamine induced memory impairment in mice. Journal of ethnopharmacology 2018; 210:198-208.

64. Qin NB, Li SG, Yang XY, Gong C, Zhang XY, Wang J, et al. Bioactive terpenoids from Silybum marianum and their suppression on NO release in LPS-induced BV-2 cells and interaction with iNOS. Bioorganic and medicinal chemistry letters 2017b; 27(10):2161-2165.

65. Das SK, Mukherjee S, Vasudevan DM. Medicinal properties of milk thistle with special reference to silymarin: An overview. Nat Prod Rad 2008; 7:182-192.

66. Cardile AP, Mbuy GK. Anti-herpes virus activity of silibinin, the primary active component of Silybum marianum. Journal of Herbal Medicine. 2013; 3(4):132-136.

67. Maghrani M, Zeggwagh NA, Lemhadri A, Amraoui ME, Michel JB, Eddouks M. Study of the hypoglycacemic activity of Fraximus excelsior and Silybum marianum in an animal model of type 1 diabetes mellitus. Journal of Ethnopharmacology. 2004: 91:309-316.

68. Qin NB, Hu X, Li S, Wang J, Li Z, Li D, et al. Hypoglycemic effect of silychristin A from Silybum marianum fruit via protecting pancreatic islet $\beta$ cells from oxidative damage and inhibiting $\alpha$-glucosidase activity in vitro and in rats with type 1 diabetes. Journal of Functional Foods. 2017c; 38:168-179.

69. Derosa G, D'Angelo A, Maffioli P. The role of a fixed Berberis aristata/Silybum marianum combination in the treatment of type 1 diabetes mellitus. Clinical Nutrition. 2016; 35(5):10911095.

70. Ebrahimpour-Koujan SE, Gargari BP, Mobasseri M, Valizadeh H, Jafarabadi MA. Effects of Silybum marianum (L.) Gaertn. (Silymarin) extract supplementation on antioxidant status and hs-CRP in patients with type 2 diabetes mellitus: A randomized, triple-blind, placebo-controlled clinical trial. Phytomedicine. 2015; 22:290-296.

71. Ebrahimpour- Koujan SE, Gargari BP, Mobasseri M, Valizadeh $\mathrm{H}$, Jafarabadi MA. Lower glycemic indices and lipid profile among type 2 diabetes mellitus patients who received novel dose of Silybum marianum (L.) Gaertn. (silymarin) extract supplement: A Triple-blinded randomized controlled clinical trial. Phytomedicine. 2018; 44:39-44.

72. Vilahur G, Casaní L, Peña E, Crespo J, Juan-Babot O, Ben-Aicha $\mathrm{S}$ et al. Silybum marianum provides cardioprotection and limits adverse remodeling post-myocardial infarction by mitigating oxidative stress and reactive fibrosis. International Journal of Cardiology, 2018.

73. Ulas T, Tursun I, Demir ME, Dal MS, Buyukhatipoglu $\mathrm{H}$. Comment on: Infusion of lin-/sca-1+ and endothelial progenitor cells improves proinflammatory and oxidative stress markers in atherosclerotic mice. International journal of cardiology. 2013; 164(1):128.

74. Erel 0. A new automated colorimetric method for measuring total oxidant status. Clinical biochemistry. 2005; 38(12):11031111.

75. Erel 0. A novel automated method to measure total antioxidant response against potent free radical reactions. Clinical biochemistry. 2004; 37(2):112-119.

76. Shaker E, Mahmoud H, Mnaa S. Silymarin, the antioxidant component and Silybum marianum extracts prevent liver damage. Food and Chemical Toxicology. 2010; 48(3):803-806.

77. Aghazadeh S, Amini R, Yazdanparast R, Ghaffari SH. Antiapoptotic and anti-inflammatory effects of Silybum marianum in treatment of experimental steatohepatitis. Experimental and toxicologic pathology. 2011; 63(6):569-574.

78. Zhu SY, Jiang N, Yang J, Tu J, Zhou Y, Xiao X et al. Silybum marianum oil attenuates hepatic steatosis and oxidative stress in high fat diet-fed mice. Biomedicine and Pharmacotherapy 2018; 100:191-197.

79. Albassam AA, Frye RF, Markowitz JS. The effect of milk thistle (Silybum marianum) and its main flavonolignans on CYP2C8 enzyme activity in human liver microsomes. Chemicobiological interactions 2017; 271:24-29.

80. Doehmer J, Weiss G, McGregor GP, Appel K. Assessment of a dry extract from milk thistle (Silybum marianum) for interference with human liver cytochrome-p450 activities. Toxicology in Vitro 2011; 25:21-27.

81. Jedlinszki N, Kálomista I, Galbács G, Csupor D. Silybum marianum (Milk thistle) products in Wilson's disease: a treatment or a threat?. Journal of Herbal Medicine. 2016; 6(3):157-159.

82. Sayyah M, Boostani H, Pakseresht S, Malayeri A. Comparison of Silybum marianum (L.) Gaertn. With fluoxetine in the treatment of Obsessive-Compulsive Disorder. Progress in Neuro-Psychopharmacology and Biological Psychiatry. 2010; 34(2):362-365.

83. Toklu HZ, Akbay TT, Velioglu-Ogunc A, Ercan F, Gedik N, Keyer-Uysal M et al. Silymarin, the antioxidant component of Silybum marianum, prevents sepsis-induced acute lung and brain injury. Journal of Surgical Research 2008; 145(2):214222.

84. Toklu HZ, Akbay TT, Erkanli G, Yuksel M, Ercan F, Sener G. Silymarin, the antioxidant component of Silybum marianum, protects against burn-induced oxidative skin injury. Burns 2007; 33:908-916. 
85. Cullere M, Zotte AD, Celia C, Monterrubi ALR, Gerencser Z Szendro $\mathrm{Z}$ et al. Effect of Silybum marianum herb on the productive performance, carcass traits and meat quality of growing rabbits. Livestock Science 2016; 194:31-36.

86. Kosina P, Dokoupilova A, Janda K, Sladkova K, Silberova P, Pivodova V et al. Effect of Silybum marianum fruit constituents on the health status of rabbits in repeated 42-day fattening experiment. Animal Feed Science and Technology 2017; 223:128-140.

87. Skottova N, Krecman V. Silymarin as a potential hypocholesterolaemic drug. Physiol Res 1998; 47:1-7.

88. Jadhav GB, Upasani CD. Antihypertensive effect of Silymarin on DOCA salt induced hypertension in unilateral nephrectomized rats. Orient Pharm Exp Med 2011; 11:101106.
89. Kittur S, Wilasrusmee S, Pedersen WA, et al. Neurotrophic and neuroprotective effects of milk thistle (Silybum marianum) onneurons in culture. J Mol Neurosci 2002; 18(3):265-269.

90. Bhatia N, Zhao J, Wolf DM, Agarwal R. Inhibition of human carcinoma cell growth and DNA synthesis by silibinin, an active constituent of milk thistle: comparison with silymarin. Cancer Letters 1999; 147:77-84.

91. Alhidary IA, Rehman Z, Khan RU, Tahir M. Anti-aflatoxin activities of milk thistle (Silybum marianum) in broiler. World's Poultry Science Journal 2017; 73: 2-7

92. Fanoudi S, Alavi MS, Karimi G, Hosseinzadeh H. Milk thistle (SilybumMarianum) as an antidote or a protective agent against natural or chemical toxicities: a review, Drug and Chemical Toxicology 2018, DOI: 10.1080/01480545.2018.1485687 